цілому, що буде відповіддю і на мою творчість, на синтез змісту і форми, без пріоритету одного над другим» [2].

По суті, це тема «Таємної вечері», яку порушували багато мистців, серед яких Стороженко особливо виділяв Леонардо да Вінчі («Таємна вечеря», фреска, 1495-1497) та Сальвадора Далі («Таємна вечеря», 1955) (використання симетрії в побудові композиції якого було суголосним Стороженковій концепції). Проаналізувавши варіації на цю тему зазначимо, що вирішення теми Стороженком $є$ до певної міри новаторським.

Варто зауважити органічність поєднання реальності з метафорами, що складаються у філософські узагальнення і становлять унікальність полотна «Передчуття Голгофи» Миколи Стороженка, що стало концептуалізацією його світорозуміння й світовідчуття, вивершення ірраціонального над раціональним.

\title{
Література:
}

1. В. Войтович. Микола Стороженко. Альбом. К., Дніпро, 2008. 176 с.

2. Микола Стороженко. Передчуття Голгофи. До 85 річниці з дня народження. К., 2013. [Б. в.].

3. Микола Стороженко - художник, педагог, людина: зб. тез доповідей наук.-практ. конф., Київ, 08 листопада 2018 р. - К., 2018. - 37 с.

DOI https://doi.org/10.30525/978-9934-26-004-9-60

\section{ПИТАННЯ КОЛЬОРОУТВОРЕННЯ В КОНТЕКСТІ СУЧАСНИХ ТЕКСТИЛЬНИХ ПРАКТИК}

\author{
Печенюк Т. Г. \\ кандидат мистеитвознавства, доцент, \\ завідувачка кафедри художнього текстилю \\ Львівської національної академї мистецтв \\ м. Львів, Украӥна
}

Колір посідає чи не найголовніші позиції в різних сферах мистецьких та дизайнерських практик, серед яких і практики сучасного художників текстилю. Свого часу саме художня тканина стала об'єктом представлення ідей живописної метафізики початку XX ст., де колір розглядався як матеріалізоване світло. Прикладом чого може бути апробація теоретичних ідей Роберта Делоне у прикладних роботах його 226 
дружини Соні Делоне, де у текстильних абажурах і завісах на вікна ми зустрічаємо мотив матерії пронизаної світлом [2, с. 107]. Разом 3 тим, багаторічний досвід вивчення феномену кольору, все більше давав підстави знаходити спорідненість ключових визначень кольорів з тим чи іншим аспектом кольороутворення в тестилі. Згадаймо лише таку незначну з точки зору «високого мистецтва» дрібничку, як відбілювання тканини. Свого часу дослідник кольору Ян Балека згадує неймовірно цікавий фрагмент 3 коптської апокрифічної євангелії про те, що: «Господь увійшов до красильні Левія, взяв 72 (тканини різного забарвлення), кинув їх до чану і дістав їх білими. I сказав Господь: Так прийшов і Син людський як фарбувальник» [1, с. 15].

Термін кольороутворення у практичному сенсі слід розглядати як застосування того чи іншого способу змішування носіїв кольорових субстанцій. Новітнє мистецтво художнього текстилю послуговується передусім текстильними матеріалами, діапазон яких значно розширився у мистецькому просторі. Використання саме текстильних матеріалів, як носіїв кольору, в професійному середовищі розглядається як традиційна сфера, натомість залучення «не текстильних» матеріалів та засобів - це сфера новаційних, експериментальних текстильних практик. Чому поєднання цих аспектів важлива у контексті кольороутворення у мистецтві художнього текстилю? Ймовірно тому, що художня тканина давно вийшла за межі своїх традиційних естетико-функціональних якостей i трансформувалася у простір творчих пошуків, реалізації авторських ідей та формування певних смислів як у прикладній (дизайнерській) сфері, так і в галузі Арт текстилю, чи то contemporary art - вільної, особистісної емоційної рефлексії (відтворення), яка спирається на авторську техніку виконання, де носіям кольору приділяється особлива увага. Підтвердження цієї тези можна знайти оглядаючи, приміром, матеріали Венеційської біенале сучасного мистецтва 2017 року, переважна більшість творів якої промовляла до глядачів «текстильною мовою» (матеріали, засоби, технологіi), репрезентуючи при цьому твори найрізноманітніших форматів, тем i концептів, що належали митцям різних сфер та напрямів.

В теорії кольору існує визначення про існування двох видів змішування кольорів: оптичного (адитивного) та механічного (субтрактивного). 3 поміж різних мистецьких феноменів «художня тканина» активно використовує обидва способи змішування. В основі «текстильної поліхромії» лежить різноманітність технік, які набули розвитку від давніх часів. I якщо раніше для визначення традиційної якості, ми окреслювали наявність тих чи інших текстильних технік у їх приналежності до певної країни, території, то нині - у XXI столітті процеси глобалізації та неймовірні можливості культурних комунікацій 
значно розширили спектр матеріально-технологічних якостей не лише знаних, але й адаптованих в творчій спільноті цього мистецтва в межах нашого глобального світу. Відмінними залишаються пріоритети, тобто техніки (технології), котрим надаються переваги в тій чи іншій культурній традиції. Отож, слід розглянути основні способи «змішування» кольорів у системі текстильної поліхромії, які присутні в різних текстильних практиках $\mathrm{i}$ відіграють вагому роль у кольороутворенні.

Свого часу авторкою цієї статті була проведена класифікація художньої тканини за способом декорування: 1) структурна орнаментація; 2) поверхнева орнаментація [2, с. 108].

Сучасна мистецька практика не тільки актуалізувала дану класифікацію, але й розширила технологічний спектр ії основних підвидів. Нагадаємо, що «структурна орнаментація» - це одночасний процес створення тканини та іiі декорування. Тоді як «поверхнева орнаментація»це декорування вже готового полотна. Кожен із підвидів має більший чи менший перелік технологічних процесів, що забезпечують умови необхідного кольороутворення згідно творчого задуму.

«Структурна орнаментація» охоплює наступні техніки: ткацтво (ремізне, килимове, гобеленове, жакардове), плетіння, в'язання (трикотажне полотно). Кожний різновид ткацтва має своє розгалуження, що залежить від технологічних особливостей. Слід зазначити, що плетіння, на думку дослідників, передувало на наших землях традиційній техніці ткання. Щодо в'язання, то в сучасному світі воно має технологічні відмінності з традиційним плетінням. В контексті новацій другої половини $\mathrm{XX}$ століття активного поширення серед фахівців художнього текстилю набули інші техніки, які теж можна класифікувати як «структурну орнаментацію». Мова йде про «валяння» (повсть), «клейову техніку» та «ручно черпаний папір». 3 приводу останніх слід детальніше зупинитися на причинах, чому їх можна розглядати в якості «структурної орнаментації» сучасного мистецтва художнього текстилю, адже саме ці техніки значно розширили діапазон оптичного змішування в текстильних практиках.

Нагадуємо, що основою будь якої тканини є нитка, яка сформована у спосіб сплетіння (скручування) певних волокон (натуральних, штучних, синтетичних тощо). Серед натурального волокнистого матеріалу ми розрізняємо волокна рослинного та тваринного походження. У свою чергу, різноманіття рослинних волокон (бавовна, льон, конопля, джут, кукурудза, кропива, кенаф, сизаль, ін.) має спільну основу - целюлозу, що $\epsilon$ природнім полімером, 3 волокнистою структурою оболонки рослинних клітин. Целюлоза міститься і в деревині, яка традиційно постачає структурний матеріал для виготовлення паперу. Саме така спільність 228 
«матеріальної» основи створення певної структури/площини, як окремішнього (не механізованого) способу творчих інспірацій художника, сприяли тому, що в другій половині XX століття мистецькі експерименти 3 целюлозним волокном призвели до залучення «рукотворного» паперу, що адаптував назву «ручно черпаного» паперу (від процесу створення), у простір сучасних мистецьких текстильних практик.

Окремим проявом таких експериментів стала поява ще однієї техніки, що також спиралася на застосування волокон рослинного походження, «клейової». На відміну від «ручно черпаного» паперу з його сталими технологічними вимогами, особливість клейової техніки передбачає використання не лише целюлозного волокнистого матеріалу, але й різноманітних ниток та інших матеріальних компонентів (клаптиків тканин, рослин, ін.), що з'єднуються в єдину структуру за допомогою певних клейових речовин для збереження цільності (міцності) поверхні твору. Звертаючись до ще однієї, згаданої вище, техніки «валяння» (повсть), то вона також належить до підвиду «структурної орнаментації» художньої тканини з тою лише відмінністю, що застосовуються волокна тваринного походження, які мають «білкову» основу i дещо іншу волокнисту якість, яка не потребує для з'єднання додаткових клейових речовин, але має складний технологічний процес «поєднання» цих волокон в єдину тканину.

Детальний аналіз усіх вищезгаданих текстильних технік, що належать до підвиду «структурної орнаменації» дають підстави стверджувати, що в цій частині мистецьких практик використовуються два види змішування: «механічне» (фарбування волокон, пряжі, готових тканин/виробів) та «оптичне» (поєднання різнокольорових волокон i ниток у технологічних процесах прядіння, ткання, валяння, формування ручно черпаного паперу та клейової техніки). Як приклад, можна навести використання багатоколірного піткання (з двох, трьох і більше ниток) в гобеленовому, чи килимовому ткацтві, або наявність двох різнокольорових систем основи та піткання в ремізному ткацтві, що відтворюють на поверхні виробу ефект подібний до пуантилістичного живопису у малярстві.

Щодо іншого підвиду «поверхневої орнаментації», то відповідні їй текстильні техніки [2. с. 114-121] за своїми характеристиками подібні до малярських технік, отож і прикладами кольороутворення (як оптичного так і механічного) на поверхні тканини можуть бути аналогічні способам нанесення кольорових плям лише з тою відмінністю, що носіями цих плям будуть не тільки фарби, але й текстильні компоненти. Лише в розписі (вільний розпис, батик), або у фарбуванні тканин застосовуються барвники, які своїми якостями не поступаються фарбам в малярських техніках. Тому перекриття однієї кольорової плями іншою на тканині 
слід розглядати як «лесирування» (накладання тонкого шару прозорих, чи напівпрозорих фарб на просохлу поверхню) - технічний прийом живопису, який належить до механічного способу змішування. Натомість, прикладом оптичного змішування в цій підгрупі може бути техніка «мармурування», яка з'явилася внаслідок появи текстильних барвників, що мають вигляд різноманітних фарбових сполук, що дозволяють одномоментно відтворювати багатоколірні фактурноколористичні поєднання.

У підсумку слід відзначити, що запропонована проекція теоретичних питань кольорознавства на мистецькі практики сучасного художнього текстилю в жодній мірі не обмежує простір можливих сфер «прикладного кольорознавства». Разом з тим, вона засвідчує емоційносмислову поліфонічність сучасних текстильних практик, які можуть відтворити будь яку авторську ідею за допомогою широкого спектру кольороутворення за допомогою текстильних носіїв кольору.

\title{
Література:
}

1. Балека Я. Синий - цвет жизни и смерти. Метафизика цвета. М: Исусство-XXI век, 2008.410 с.

2. Печенюк Т. Кольорознавство. К: «Грані-Т», 2009, 198 с.

DOI https://doi.org/10.30525/978-9934-26-004-9-61

\section{М. І. РОСТОВЦЕВ ЯК ДОСЛІДНИК АНТИЧНОГО МИСТЕЦТВА ПІВНІЧНОГО ПОНТУ}

\author{
Русясва М. В. \\ кандидат мистецтвознавства, доцент, \\ доцент кафедри теорії та історії мистецтва \\ Національної академії образотворчого мистецттва і архітектури \\ м. Київ, Украӥна
}

Початок систематичних штудій античного мистецтва Північного Понту припадає на першу третину XX ст. Найбільший внесок на цьому етапі зробив Михайло Іванович Ростовцев (1870-1952) - титан давньої історії, один з видатних науковців-істориків XX ст., світовий авторитет 3 елліністичної та римської історії, професор Сльського університету, почесний доктор Оксфорда, Кембриджа i Гарварда, президент Американської історичної асоціації. 